\title{
Heterotrophic dinoflagellate fecal pellet production: grazing of large, chain-forming diatoms during upwelling events in Monterey Bay, California
}

\author{
K. R. Buck*, R. Marin III, F. P. Chavez \\ Monterey Bay Aquarium Research Institute, 7700 Sandholdt Road, Moss Landing, California 95039, USA
}

\begin{abstract}
An athecate phagotrophic dinoflagellate (Gyrodinium sp.) ingests chain-forming diatoms that are abundant during upwelling events in Monterey Bay, CA, USA, and contiguous waters. The chains are digested and egested with a peritrophic membrane covering the fecal pellet, consistent with earlier reports from high productivity environments. The maximum abundance of the

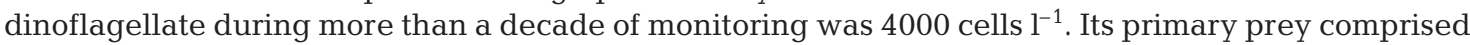
chains of centric diatoms such as Chaetoceros spp. or Skeletonema spp., although Pseudo-nitzschia spp. were also observed in the dinoflagellate's fecal pellets. Maximum grazing by this dinoflagellate represented $10 \%$ of the total phytoplankton biomass. Our observations suggest a lesser role of large heterotrophic dinoflagellates in the ecology of central California waters compared to other regions.
\end{abstract}

KEY WORDS: Heterotrophic dinoflagellates $\cdot$ Microzooplankton grazing

Resale or republication not permitted without written consent of the publisher

\section{INTRODUCTION}

The role of microzooplankton (principally dinoflagellates and ciliates) in the microbial foodweb has been studied extensively and was originally thought to revolve primarily around their effect upon pico- and nanoplankton (Azam et al. 1983). However, there is mounting evidence that some microzooplankton are capable of grazing larger prey (Bursa 1961, Elbrachter 1991, Hansen 1991, Thomsen et al. 1991, Jacobson \& Anderson 1992, Strom \& Strom 1996). In particular, gymnodinoid dinoflagellates have been identified as being capable of ingesting phytoplankton, usually diatoms, that are larger in terms of biovolume than the grazer itself (Bursa 1961, Elbrachter 1991). Quantitative grazing studies have suggested that microzooplankton grazing may be responsible for the removal of a substantial amount of the daily primary productivity in coastal and/or upwelling regions (Odate \& Maita 1990, Neuer \& Cowles 1994, 1995, Strom \& Strom 1996, Strom et al. 2001).

In 2 previous studies we have shown that athecate dinoflagellates are capable of ingesting chains of diatoms (Buck et al. 1990, Buck \& Newton 1995). Complete digestion of the cellular contents of the diatoms occurs in the vacuole. Relatively intact siliceous frustules and girdle bands, in a relatively tightly packed fecal pellet surrounded by a peritrophic membrane, are egested. Previous reports of small dinoflagellate fecal pellets have been from disparate environments: Antarctic sea-ice (Buck et al. 1990), Antarctic water column (Nothig \& von Bodungen 1989, Gonzalez 1992, Gowing et al. 1998, Beaumont et al. 2002) and a small protected embayment in Washington state (Buck \& Newton 1995); however, there is a remarkable consistency in the morphology of the pellets.

The formation of this type of fecal pellet increases the flux of biogenic silica from the upper water column relative to POC (particulate organic carbon). Dinoflagellate grazing may also exercise top-down control on diatom biomass buildup. Herein, we report on an athecate dinoflagellate (Gyrodinium sp.) that is abundant in the relatively open ocean waters of Monterey Bay and contiguous waters of the California Current and preys upon a diversity of chain-forming diatoms. 


\section{MATERIALS AND METHODS}

Samples used in this study came from surface water taken as part of routine sampling in Monterey Bay in 1993 and 2000 (Pennington \& Chavez 2000) and from Monterey Bay and contiguous waters of the California Current sampled during a multi-ship experiment in 1995 (see Brzezinski et al. 1997). Stations sampled varied in distance offshore (5 to $56 \mathrm{~km}$ : Table 1). Aliquots of surface water collected with a CTD and Niskin bottles were preserved with glutaraldehyde (final concentration $2 \%$ ); $25 \mathrm{ml}$ of the preserved seawater were filtered through $0.2 \mu \mathrm{m}$ pore size, $25 \mathrm{~mm}$ diameter, polycarbonate filters and placed on a coverslip with a drop of Zeiss immersion oil between filter and coverslip. Epifluorescence enumerations and biomass estimates following standard procedures (Buck et al. 1992a). Aliquots were prepared for scanning electron microscopy (SEM) by filtration through polycarbonate filters, followed by rinsing with distilled water and air drying; $10 \mathrm{ml}$ subsamples from a recent expedition (March 2000) were settled and counted on an inverted microscope to determine the abundance and content of fecal pellets. The removal of phytoplankton biomass by Gyrodinium sp. was calculated using Gyrodinium sp. clearance $\left(2.7 \times 10^{4}\right.$ body vol $\mathrm{h}^{-1}$, Hansen 1992$)$ and the concentration of phytoplankton present (Table 1).

Table 1. Stations (distance from shore, km), Gyrodinium sp. abundance (cells $\mathrm{l}^{-1}$ ) and carbon concentration $\left(\mu \mathrm{g}^{-1}\right)$, phytoplankton carbon concentration $\left(\mu \mathrm{g} \mathrm{l}^{-1}\right)$, dominant phytoplankton genera, and calculated percent of phytoplankton biomass removed daily by Gyrodinium sp. grazing in surface waters of Monterey Bay from July 1993 to March 2000. These samples represent only the highest concentrations of Gyrodinium during 8 yr of sampling

\begin{tabular}{|c|c|c|c|c|c|}
\hline $\begin{array}{l}\text { Cruise, } \\
\text { Stn }\end{array}$ & $\begin{array}{l}\text { Gyrodini } \\
\text { Abundance }\end{array}$ & $\begin{array}{l}\text { ium sp. } \\
\text { Carbon }\end{array}$ & $\begin{array}{l}\text { Phyto- } \\
\text { plankton } \\
\text { carbon }\end{array}$ & $\begin{array}{c}\text { Dominant } \\
\text { phyto- } \\
\text { plankton }\end{array}$ & $\begin{array}{l}\% \text { phyto- } \\
\text { plankton } \\
\text { grazed }\left(\mathrm{d}^{-1}\right)\end{array}$ \\
\hline \multicolumn{6}{|l|}{ July 1993} \\
\hline C1 (5) & 720 & 11.2 & 304 & Chaetoceros & 6.0 \\
\hline M1 (19) & 1680 & 15.2 & 781 & Chaetoceros & 7.6 \\
\hline H3 (19) & 1600 & 17.2 & 583 & Chaetoceros & 8.8 \\
\hline Midpoint (42) & 960 & 10.3 & 348 & Chaetoceros & 5.3 \\
\hline \multicolumn{6}{|l|}{ CoOP (1995) } \\
\hline $6(56)$ & 440 & 2.1 & 128 & $\begin{array}{l}\text { Skeletonema/ } \\
\text { Chaetoceros }\end{array}$ & 1.1 \\
\hline $7(45)$ & 280 & 0.4 & 26 & Chaetoceros & 0.2 \\
\hline 8 (33) & 440 & & 108 & Skeletonema & \\
\hline $58(37)$ & 1120 & 3.2 & 690 & Chaetoceros & 1.6 \\
\hline $67(15)$ & 3800 & 11.4 & 221 & $\begin{array}{l}\text { Skeletonema/ } \\
\text { Thalassiosiral }\end{array}$ & \\
\hline $94(56)$ & 520 & 12.2 & 671 & $\begin{array}{l}\text { Chaetoceros } \\
\text { Skeletonema }\end{array}$ & $\begin{array}{l}5.4 \\
0.5\end{array}$ \\
\hline \multicolumn{6}{|l|}{ March 2000} \\
\hline C1 (5) & 1920 & 27.3 & 125 & Chaetoceros & 6.5 \\
\hline M1 (19) & 1600 & 38.9 & 292 & $\begin{array}{l}\text { Chaetoceros/ } \\
\text { centric }\end{array}$ & 10.4 \\
\hline
\end{tabular}

\section{RESULTS AND DISCUSSION}

The predominant large dinoflagellate (a Gyrodinium species) was approximately $100 \mu \mathrm{m}$ in length and $50 \mu \mathrm{m}$ in width and was teardrop shaped (Figs. 1 to 4 ). We have not attempted to assign it to a species, but it was similar in size and shape to G. spirale (Hansen 1992). The size, shape and particular yellow-green fluorescence imparted by glutaraldehyde fixation (Figs. 1 to 4) facilitated identification and enumeration. The presence of Gyrodinium spp. in the surface water samples that we routinely processed for phytoplankton and aplastidic protist enumeration from Monterey Bay is not unusual; however, high abundances $\left(>10^{3}\right.$ cells $\mathrm{l}^{-1}$ ) are not a consistent feature of the Monterey Bay upwelling system. Of the $>650$ time series stations that we have analyzed since 1990, $<5 \%$ contained large $\left(>30000 \mu^{3}\right.$ ) Gyrodinium sp., and only $2 \%$ had abundances $>1000$ cells $\mathrm{l}^{-1}$. We have focused on 3 of the events when abundance of this large heterotrophic dinoflagellate was high at several stations (Table 1). Absolute carbon concentration associated with Gyrodinium sp. and that relative to phytoplankton biomass during these 3 events was usually moderate, although the March 2000 values were higher (Table 1). Previous studies (Hansen 1991, Neuer \& Cowles 1994, Buck \& Newton 1995) have reported higher biomass, both absolute and relative to that of phytoplankton.

Most of the Gyrodinium sp. we observed possessed conspicuous inclusions (Figs. 1 to 4). In a number of instances the composition of these inclusions could be determined to the broad taxonomic level of centric/pennate diatoms (Fig. 4), and the diameter of the chain could be measured. Coincident with the high abundances of Gyrodinium sp. were fecal pellets of a size, shape and composition consistent with dinoflagellate produced pellets (Figs. 5 to 8). Dinoflagellate fecal pellets we observed in Monterey Bay and contiguous waters are somewhat smaller in size $(60 \times 44 \mu \mathrm{m})$ than the Gyrodinium sp. that produces them $(95 \times$ $58 \mu \mathrm{m})$. They comprise intact diatom frustules and girdle bands, usually of a chain forming taxon, and usually have a membrane surrounding the pellet (Figs. 5 to 8). Pellets were from the genera Skeletonema, Chaetoceros, Thalassiosira, Pseudo-nitzschia and Minidiscus. In most, but not all, instances the cells that constituted the pellets were devoid of protoplasm, lending the pellets a 

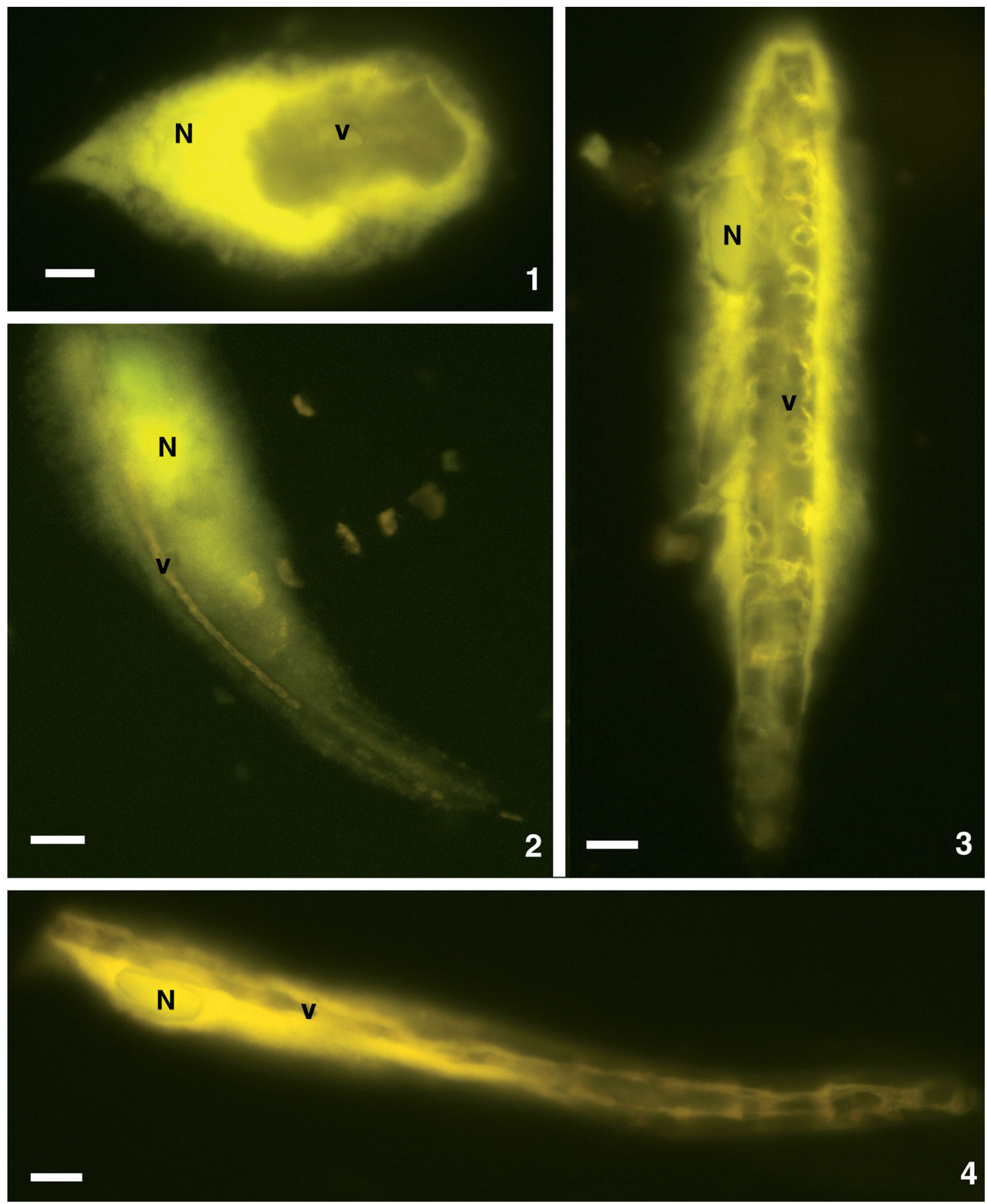

Figs. 1 to 4. Gyrodinium sp. Epifluorescence micrographs of glutaraldehyde preserved specimens from Monterey Bay and contiguous waters, demonstrating plasticity of dinoflagellate and size of food particles (chains of centric diatoms) it is able to ingest. N: nucleus; $\mathrm{v}$ : food vacuole. Scale bars $=10 \mu \mathrm{m}$ 


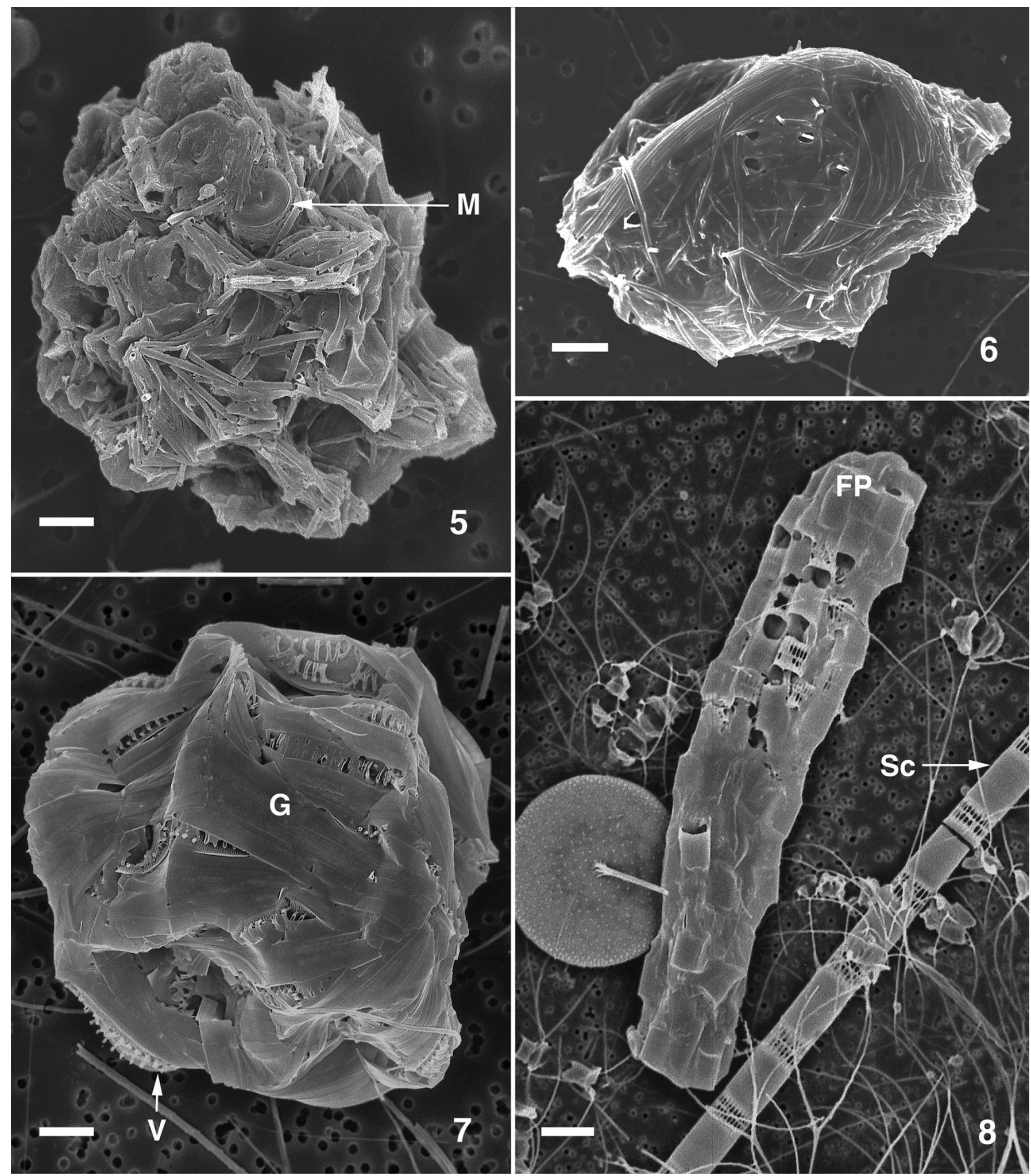

Figs. 5 to 8. Scanning electron micrographs of fecal pellets probably produced by Gyrodinium sp. in Monterey Bay and contiguous waters. Fig. 5. Fecal pellet comprising Chaetoceros sp. setae and centric diatom Minidiscus trioculatus (M). Fig. 6. Fecal pellet comprises Chaetoceros sp. setae. Fig. 7. Fecal pellet comprises large diameter centric diatom (Thalassiosira sp. cf.) valves (V) and girdle bands (G). Fig. 8. Fecal pellet comprises folded chain of Skeletonema costatum, similar to unincorporated chain (Sc) on right; Chaetoceros sp. and Thalassiosira sp. cells are also vivible in background. Scale bars $=10 \mu \mathrm{m}$ 
translucent quality when viewed with transmitted light on a compound microscope and rendering them invisible when viewed with epifluorescence. The composition of the pellets reflected the assemblage of diatoms present in the surface waters (Table 1). Although most pellets comprised a single taxon/chain, there were instances where the pellet was comprised of multiple taxa (Fig. 6). Several reports from the Antarctic have also described fecal pellets of probable dinoflagellate origin containing more than a single species of prey (Nothig \& von Bodungen 1989).

The most recent samples (March 2000, Table 1) contained 11000 and 4000 pellets $l^{-1}$ for Stns C1 and M1, respectively. These concentrations are high in relation to the numbers of Gyrodinium sp. present (1920 and $1600 \mathrm{l}^{-1}$, respectively). Few other studies have reported discrete fecal pellet concentrations in the water column. One of these reported modest concentrations $\left(68 \mathrm{l}^{-1}\right.$ : Nothig \& von Bodungen 1989). The ratio of approximately 5 pellets: 1 dinoflagellate we observed is suprisingly close to the maximum ratio of 3 pellets: 1 dinoflagellate calculated from flux studies in the Ross Sea polyna for a somewhat larger dinoflagellate (Gowing et al. 2001). The high abundance of Gyrodinium sp. fecal pellets relative to its abudance could be due to several reasons: (1) Calculation of the sinking rate of these pellets (Small et al. 1979) based upon their mean (data not shown) volume gives relatively slow sinking rates of 13 to $22 \mathrm{~m} \mathrm{~d}^{-1}$; a 1 to $3 \mathrm{~d}$ period was posited for the lag between maximal Gyrodinium sp. concentrations in the top $10 \mathrm{~m}$ of the water column and the maximal dinoflagellate fecal pellet flux at $50 \mathrm{~m}$ in Dabob Bay, WA (Buck \& Newton 1995), which is consistent with the calculated sinking rate. (2) Mixing of the upper water column would tend to decrease the fecal pellet sinking rate. (3) The numbers of Gyrodinum sp. could have been underestimated due to its fragility.

During a 1995 experiment, based on the retention of biogenic silica in the upper water column, Brzezinski et al. (1997) suggested that the grazing pressure on diatom stocks was low. However, grazing by dinoflagellates with the subsequent production of fecal pellets and their retention in the upper water column could also produce high biogenic silica concentrations. Using published values (Hansen 1992) to calculate ingestion of phytoplankton biomass, we estimated the potential impact that Gyrodinium sp. has on the primary producers: the high concentrations ( $>440$ cells l$^{-1}$ ) of Gyrodinium sp. we recorded for Monterey Bay could remove 1 to $10 \%$ of the phytoplankton biomass (Table 1 ).

Our observations during the 3 high Gyrodinium sp. abundance events in and offshore Monterey Bay over the past decade are in general consistent with previous reports. The Gyrodinium sp. that is most abundant during diatom blooms is able to ingest and process long chains of diatoms, and produce a fecal pellet characteristic of this type of feeding. A fecal pellet from a Gyrodinium species comprises intact frustules and girdle bands, usually of a single taxon/chain, devoid of protoplasm and surrounded by a peritrophic membrane. In the absence of any mechanism to reduce the size of the ingested diatom, such as mastication, dinoflagellates may be at a disadvantage compared to metazoan predators. However, the ability to ingest a biovolume near their own size and to digest protoplasmic contents completely are adaptations that partially overcome this disadvantage.

The ability of Gyrodinium sp. to ingest, process and egest a fecal pellet of Pseudo-nitzchia spp. is important in light of recent reports of blooms of this organism on the west coast of North America (Buck et al. 1992b, Scholin et al. 2000). The anchovy Engraulis ringens is one of the identified vectors for the transmission of domoic acid from some species of Pseudo-nitzschia up the food chain in Monterey Bay. Subsequent predation on anchovies by top predators such as pelicans and sea lions (Work et al. 1993, Scholin et al. 2000) has resulted in the predators' mortality. Predation by Gyrodinium sp. and other microzooplankton may play a role in this pathway by either concentrating the toxin prior to ingestion by anchovies, or by digesting the toxin, effectively decreasing the concentration.

During $12 \mathrm{yr}$ of sampling every 2 to $3 \mathrm{wk}$ in Monterey Bay, we have noted only 3 instances of high heterotrophic dinoflagellate concentrations; in each case, these were comprised Gyrodinium sp. Monterey Bay and contiguous waters are in an area of high primary production, and there is a regular supply of suitable prey for Gyrodinium sp., yet high abundance of this dinoflagellate is rare. When its abundance in these waters is relatively high, then its impact upon the diatom bloom appears to be minor (Table 1), much less than that suggested for this large dinoflagellate in other studies (Hansen 1991, Neuer \& Cowles 1994, Buck \& Newton 1995). A shorter duration of the diatom blooms than that necessary for dinoflagellate populations to buildup and/or suppression of Gyrodinium sp. biomass by metazoan zooplankton predators might explain this.

This study has documented another area (central Californian waters) in which a large heterotrophic dinoflagellate produces distinctive fecal pellets. Contrary to our earlier studies, in which the contents of the fecal pellets of Gyrodinium sp. demonstrated high fidelity to a single prey species (Buck et al. 1990, Buck \& Newton 1995), Gyrodinium sp. in Monterey Bay and contiguous waters has a diverse diet. While the impact of this grazer upon the phytoplankton of Monterey Bay appears to be less substantial than in other regions, it should be included in modeling efforts, and in analysis of field samples 
Acknowledgements. We thank A. Heywood and S. Strom for editorial input and thoughtful discussions. Samples were collected by T. Pennington and the crew of the RV 'Pt. Lobos'. Support for the CoOP sample collection came from NSF (OCE-9419322 to F.P.C.). Comments, editorial input and suggestions by several reviewers improved this work. Funding from the David and Lucille Packard Foundation to the Monterey Bay Aquarium Research Institute supported other aspects of this work.

\section{LITERATURE CITED}

Azam F, Fenchel T, Field JG, Gray JS, Meyer-Reil LA, Thingstad F (1983) The ecological role of water-column microbes in the sea. Mar Ecol Prog Ser 10:257-263

Beaumont KL, Nash GV, Davidson AT (2002) Ultrastructure, morphology and flux of microzooplankton faecal pellets in an East Antarctic fjord. Mar Ecol Prog Ser 245:133-148

Brzezinski MA, Phillips DR, Chavez FP, Friederich GE, Dugdale RC (1997) Silica production in the Monterey Bay, California upwelling system. Limnol Oceanogr 42: 1694-1705

Buck KR, Newton J (1995) Fecal pellet flux in Dabob Bay during a diatom bloom:contribution of microzooplankton. Limnol Oceanogr 40:306-315

Buck KR, Bolt PA, Garrison DL (1990) Phagotrophy and fecal pellet production by an athecate dinoflagellate in Antarctic sea ice. Mar Ecol Prog Ser 60:75-84

Buck KR, Bolt PA, Bentham WN, Garrison DL (1992a) Dinoflagellate cysts associated with Antarctic sea ice communities. J Phycol 28:15-18

Buck KR, Uttal-Cooke L, Pilskaln CH, Roelke DL, Villac MC, Fryxell GA, Cifuentes L, Chavez PF (1992b) Autecology of the diatom Pseudo-nitzschia australis Frenguelli, a domoic acid producer, from Monterey Bay, California. Mar Ecol Prog Ser 84:293-302

Bursa AS (1961) The annual oceanographic cycle at Igoolik in the Canadian Arctic. II. The phytoplankton. J Fish Res Board Can 18:563-615

Elbrachter M (1991) Faeces production by dinoflagellates and other small flagellates. Mar Microb Food Webs 5:189-204

Gonzalez HE (1992) The distribution and abundance of krill faecal material and oval pellets in the Scotia and Weddell Seas (Antarctica) and their role in particle flux. Polar Biol 12:81-91

Gowing MM, Garrison DL, Kunze HB, Winchell C (1998) Biological components of Ross Sea austral summer (1995/1996) particle fluxes. NZ Nat Sci 23:69

Gowing MM, Garrison DL, Kunze HB, Winchell CJ (2001)

Editorial responsibility: David Caron,

Los Angeles, California, USA
Biological components of Ross Sea short-term particle fluxes in the austral summer of 1995-1996. Deep-Sea Res I 48:2645-2671

Hansen PJ (1991) Quantitative importance and trophic role of heterotrophic dinoflagellates in a coastal pelagial food web. Mar Ecol Prog Ser 73:253-261

Hansen PJ (1992) Prey size selection, feeding rates and growth dynamics of heterotrophic dinoflagellates with special emphasis on Gyrodinium spirale. Mar Biol 114:327-334

Jacobson DM, Anderson DM (1992) Ultrastructure of the feeding apparatus and myonemal system of the heterotrophic dinoflagellate Protoperidinium spinulosum. J Phycol 28:69-82

Neuer S, Cowles TJ (1994) Protist herbivory in the Oregon upwelling system. Mar Ecol Prog Ser 113:147-162

Neuer S, Cowles TJ (1995) Comparative size-specific grazing rates in field populations of ciliates and dinoflagellates. Mar Ecol Prog Ser 125:259-267

Nothig EV, von Bodungen B (1989) Occurrence and vertical flux of faecal pellets of probably protozoan origin in the southeastern Weddell Sea (Antarctica). Mar Ecol Prog Ser 56:281-289

Odate T, Maita Y (1990) Phagotrophic grazing by dinoflagellates on diatoms during the spring phytoplankton bloom in Funka Bay. Bull Plankton Soc Jpn 36:142-144

Pennington JT, Chavez FP (2000) Seasonal fluctuations of temperature, salinity, nitrate, chlorophyll and primary production at station H3/M1 over 1989-1996 in Monterey Bay, California. Deep-Sea Res 47:947-973

Scholin CA, Gulland F, Doucette GJ, Benson S and 10 others (2000) Mortality of sea lions along the central California coast linked to a toxic diatom bloom. Nature 403:80-84

Small LF, Fowler SW, Uenlue MY (1979) Sinking rates of natural copepod fecal pellets. Mar Biol 51:233-241

Strom SL, Strom MW (1996) Microplankton growth, grazing and community structure in the northern Gulf of Mexico. Mar Ecol Prog Ser 130:229-240

Strom SL, Brainard MA, Holmes JL, Olson MB (2001) Phytoplankton blooms are strongly impacted by microzooplankton grazing in coastal North Pacific waters. Mar Biol 138:355-368

Thomsen HA, Buck KR, Bolt PA, Garrison DL (1991) Cryothecamonas armiger gen. et sp. nov. (incertae sedis) and related species from Antarctic and Danish sea ice. Can J Zool 69:1048-1070

Work TM, Beal AM, Fritz L, Quilliam MA, Silver MW, Buck KR, Wright JL (1993) Domoic acid intoxication of brown pelicans and cormorants in Santa Cruz, California. In: Smayda TJ, Shimizu Y (eds) Toxic phytoplankton blooms. Elsevier, Amsterdam, p 643-649

Submitted: February 17, 2005; Accepted: June 30, 2005 Proofs received from author(s): October 4, 2005 